\title{
FUNGSI VERBA LOKATIF DALAM KALIMAT TUNGGAL WACANA NARATIF BAHASA JAWA
}

\author{
Bayu Indrayanto dan Wahjoe Sri Irwanto \\ PBJ-FKIP Unwidha \\ bayuindra@unwidha.ac.id
}

\begin{abstract}
Abstrak
Fungsi verba lokatif dalam kalimat tunggal dalam wacana naratif bahasa Jawa bertujuan mendeskripsikan fungsi verba lokatif dalam kalimat tunggal. Data dalam penelitan ini adalah data tulis yang berasal dari majalah berbahasa Jawa yaitu majalah Damar Jati (edisi Maret-Juni 2019), Djaka Lodang (edisi MaretJuni 2019), dan Panjebar Semangat (edisi Maret-Juni 2019). Data yang diambil berupa kalimat-kalimat yang mengandung verba lokatif dengan nomina lokatif dalam wacana naratif bahasa Jawa. Pengumpulan data dalam penelitian ini menggunakan metode simak. Metode simak atau penyimakan, karena memang berupa penyimakan, teknik dasar yang dipakai adalah teknik sadap, sedangkan teknik lanjutan yang digunakan yaitu teknik catat. Hasil temuan penelitian tentang verba lokatif dapat dibedakan berdasarkan unsur pembentuk verba lokatif tersebut yaitu monomorfemis dan polimorfemis. Kemudian fungsi dalam kalimat tunggal wacana naratif bahasa Jawa berupa unsur verba lokatif dengan kebanyakan berpola $\mathrm{S}$ dan $\mathrm{P}$ (dengan kategori verba/frase verba). Sedangkan peran verba lokatif dalam kalimat tunggal wacara naratif bahasa Jawa berupa peran aktif dan peran reflektif. Dan sifat nomina lokatif yang mengikuti verba lokatif bersifat intrinsik serta takintrinsik. Kemampuan takinheren/eksternal, artinya verba itu harus diderivasikan dahulu untuk dapat menghadirkan nomina lokatif. Bahwa sifat nomina lokatif yang mengikuti verba lokatif inheren, bersifat intrinsik; nomina lokatif yang mengikuti verba lokatif takinheren, bersifat takintrinsik. Namun demikian, ada juga nomina lokatif yang mengikuti verba lokatif inheren, bersifat takintrinsik. Nomina lokatif intrinsik, artinya nomina tersebut bersifat ketat, jelas, dan sudah secara eksplisit terkandung dalam verba lokatifnya. Nomina lokatif takintrensik, artinya nomina tersebut bersifat longgar, umum (general).

Kata Kunci : kalimat tunggal, fungsi, verba lokatif
\end{abstract}

\section{PENDAHULUAN}

Verba menurut Harimurti Kridalaksana adalah kelas kata yang biasanya berfungsi sebagai predikat yang tidak mungkin berpotensi untuk diawali dengan kata 'lebih' (2011 : 226). Verba menurut Soepomo Poedjosudarmo dkk. adalah jenis kata yang menunjukkan tindakan atau perbuatan suatu makhluk (1979 : 22). 
Sumarlam dan Sujono (1996) mendefinisikan verba sebagai kategori kata yang menyatakan perbuatan, peristiwa atau keadaan yang secara dominan menduduki fungsi predikat, serta verba adalah kata-kata pada tataran klausa yang cenderung menduduki predikat dan pada tataran frasa dapat dinegatifkan dengan kata ora 'tidak'.

Berdasarkan beberapa pengertian di atas, dapat disimpulkan bahwa verba termasuk kelas kata yang menyatakan perbuatan, berfungsi sebagai predikat dalam kalimat, tidak berpotensi diawali dengan kata 'lebih' atau "luwih" dalam bahasa Jawa, dan dapat dinegatifkan dengan kata "tidak'atau "ora" dalam bahasa Jawa.

Secara sintaktis verba adalah kategori keterangan gramatikal yang mempunyai ciri-ciri sebagai berikut.

1. Verba dapat diingkarkan dengan kata 'tidak' yang sejajar dengan kata "ora" dalam bahasa Jawa, tetapi tidak dapat diingkarkan dengan kata 'bukan' yang sejajar dengan kata “ $d u d u$ ”dalam bahasa Jawa.

2. Verba tidak dapat berangkai dengan kata 'paling' yang sejajar dengan kata "dhewe" dalam bahasa Jawa sebagai makna superlatif. Jadi tidak ada bentuk seperti: ngimpi dhewe.

3. Verba memiliki fungsi utama sebagai predikat atau inti predikat di dalam kalimat meskipun pula mempunyai fungsi lain.

4. Verba aksi/verba yang mengandung makna perbuatan atau tindakan tidak dapat berangkai dengan kata yang menyatakan makna 'kesangatan' yang sejajar dengan kata "banget" dalam bahasa Jawa. Jadi tidak ada bentuk seperti: mulih banget.

5. Verba aksi dapat diikuti fungsi sintaksis keterangan yang didahului kata 'dengan' yang sejajar dengan kata "karo" atau "kanthi" dalam bahasa Jawa.

6. Verba aksi dapat dijadikan bentuk perintah, sedangkan verba proses dan keadaan tidak, misalnya: sinau ! tetapi tidak ada bentuk ngimpi !

Secara sintaktis fungsi diartikan sebagai hubungan antara unsur-unsur bahasa dilihat dari sudut pandang penyajiannya dalam ujaran (Kridalaksana, 2011: 
62). Dengan ciri-ciri fungsi sintaksis adalah urutan kata berupa frase dalam kalimat, mengacu ke tugas unsur sintaksis, peran sebuah unsur dalam satuan sintaksis yang lebih luas yaitu struktur kalimat. Sedangkan fungsi bersifat relasional, yakni adanya fungsi yang satu berhubungan dengan fungsi yang lain. Bagian fungsi terdiri atas subjek, predikat, objek, dan keterangan. Di dalam bahasa Jawa subjek disebut jejer, predikat disebut wasesa, objek disebut lesan, dan keterangan disebut panerang (Sasangka, 2008: 143-149). Pada artikel ini akan dibahas mengenai fungsi verba lokatif dalam kalimat tunggal wacana naratif bahasa Jawa.

Adapun contoh data (1) sebagai verba lokatif, penjelasannya sebagai berikut.

Data (1) Bapak nembe macul.

'Bapak baru mencangkul.'

(PS / No. 08 / 2019 / 23)

Kalimat (1) merupakan kalimat tunggal yang mengandung verba lokatif monomorfemis berupa kata macul dengan struktur kalimat:

\section{Bapak/Nom + lagi macul/FV}

$\mathrm{S}$

$\mathrm{P}$

Kata lagi macul dalam kalimat tersebut menempati fungsi $\mathrm{P}$ dan bapak menempati fungsi S. Adapun kategori yang menempati unsur pembentuk kalimat adalah Bapak sebagai nominal dan lagi maculberupa frasa verba. Kata macul mengalami perubahan fungsi kata yaitu fungsi dari kata nomina pacul.

Frasa verba lagi macul dalam kalimat tersebut merupakan verba lokatif. Di mana verba macul mengandung nomina instrumen, sesuatu alat yang digunakan untuk mencangkul yaitu di ladang atau sawah. Dengan itu, verba lokatif tersebut bersifat inheren (jenis nomina lokatif sudah tercermin di dalam verbanya). Akan tetapi, nomina yang mengikutinya bersifat takintrinsik, artinya, nomina itu bersifat longgar (tidak ketat). Ketidakketatan nomina itu ditandai dengan dapatnya bermacam-macam jenis lokatif yang mampu mengikuti verbanya. Namun demikian, meskipun nomina itu bermacam-macam, jenis nomina itu masih di 
dalam satu wadah kehiponiman. Dengan demikian, nomina lokatif pada kalimat (3) bersifat takintrinsik.

Berdasarkan data (1) tersebut penulis tertarik untuk melakukan pembahasan selanjutnya. Kertarikannya terletak pada kemampuan verba lokatif untuk menghadirkan nomina lokatif bersifat inheren dan takinheren/eksternal. Kemampuan takinheren/eksternal, artinya verba itu harus diderivasikan dahulu untuk dapat menghadirkan nomina lokatif. Diungkapkan pula oleh Chafe bahwa sifat nomina lokatif yang mengikuti verba lokatif inheren, bersifat intrinsik; nomina lokatif yang mengikuti verba lokatif takinheren, bersifat takintrinsik (dalam Verhaar, 2006). Namun demikian, ada juga nomina lokatif yang mengikuti verba lokatif inheren, bersifat takintrinsik. Nomina lokatif intrinsik, artinya nomina tersebut bersifat ketat, jelas, dan sudah secara eksplisit terkandung dalam verba lokatifnya. Nomina lokatif takintrensik, artinya nomina tersebut bersifat longgar, umum (general). Berdasarkan latar belakang tersebut, maka dapat dirumuskan tiga masalah yaitu bentuk, fungsi, makna dan peran verba lokatif dalam kalimat bahasa Jawa. Namun, dalam kajian artikel ini hanya mengkaji tentang fungsi verba lokatif dalam kalimat tunggal wacana naratif bahasa Jawa.

\section{METODE}

Metode merupakan cara mendekati, mengamati, menganalisis gejala yang ada (Harimurti Kridalaksana, 2011: 136). Data dalam penelitan ini adalah data tulis yang berasal dari majalah berbahasa Jawa yaitu majalah Damar Jati (edisi Maret-Juni 2019), Djaka Lodang (edisi Maret-Juni 2019), dan Panjebar Semangat (edisi Maret-Juni 2019) dan data lisan yang diucapkan oleh penutur asli bahasa Jawa. Data yang diambil berupa kalimat-kalimat yang mengandung verba lokatif dengan nomina lokatif dalam wacana naratif bahasa Jawa. Data tersebut diklasifikasikan sesuai dengan golongannya. Data yang terjaring berjumlah banyak, tetapi hanya sedikit yang diambil sebagai bahan analisis, sejumlah data tersebut dapat mewakili permasalahan.

Populasi adalah keseluruhan individu dan subjek yang diteliti (Edi Subroto, 1992: 91). Adapun populasi dalam penelitian ini adalah semua kalimat 
yang mengandung verba lokatif dalam bahasa Jawa yang terdapat pada sumber data. Sampel adalah sebagian dari populasi yang dijadikan objek penelitian langsung, dianggap mewakili populasi secara keseluruhan (Edi Subroto, 1992: 91). Pengambilan sampel dalam penelitian ini adalah purposive sampling, maksudnya penentuan sampel berdasarkan pada kepentingan peneliti secara selektif. Sampel penelitian ini berupa kalimat yang mengandung verba lokatif dalam bahasa Jawa yang terdapat dalam sumber data. Pengumpulan data dalam penelitian ini menggunakan metode simak. Metode simak atau penyimakan, karena memang berupa penyimakan: dilakukan dengan menyimak, yaitu menyimak penggunaan bahasa (Sudaryanto, 1993: 2). Adapun teknik dasar yang dipakai adalah teknik sadap, sedangkan teknik lanjutan yang digunakan yaitu teknik catat.

Teknik sadap itu digunakan sebagai teknik dasar dalam pengumpulan data tulis. Menurut Sudaryanto penerapan teknik sadap pada data tulis diwujudkan dengan cara menyimak (1993 : 2). Di dalam hal ini, teknik lanjutan yang digunakan yaitu teknik catat. Menurut Sudaryanto teknik catat adalah pencatatan data yang menggunakan alat tulis tertentu dan dapat dipandang sebagai teknik lanjutan (1993 : 5). Penerapan teknik catat yaitu: data dicatat pada kartu data yang telah disiapkan dengan diberi tanda sesuai kebutuhan dan masalah yang diteliti sehingga akan mempermudah untuk mengklasifikasi data dan analisis.

Adapun langkah-langkah pengumpulan data adalah sebagai berikut. Langkah pertama, peneliti menyimak sumber data tulis yang terdapat pada sampel data yang telah ditentukan. Langkah kedua, peneliti mencari kalimat-kalimat yang mengandung verba lokatif untuk dijadikan sebagai data penelitian. Selanjutnya, peneliti memberi tanda pada kalimat-kalimat yang akan dijadikan data dengan bolpen atau spidol berwarna. Langkah berikutnya adalah penerapan teknik lanjutan yaitu teknik catat. Peneliti mencatat kalimat-kalimat yang mengandung verba lokatif ke dalam kartu data, kemudian diklasifikasikan berdasarkan masalah yang ditentukan. 


\section{HASIL DAN PEMBAHASAN}

\section{Hasil Penelitian}

Hasil temuan penelitian tentang verba lokatif dapat dibedakan berdasarkan unsur pembentuk verba lokatif tersebut yaitu monomorfemis dan polimorfemis. Bentuk verba lokatif yang berupa monomorfemis, adapun penjelasannya adalah sebagai berikut.

Tabel 1. Verba Lokatif Monomorfemis

\begin{tabular}{c|c}
\hline VERBA LOKATIF & DESKRIPSI TEMPAT (di) \\
\hline adzan & masjid/ surau \\
\hline khotbah & masjid \\
\hline masak & dapur \\
\hline ramban & ladang \\
\hline dhedhe & matahari \\
\hline angon & kebun/ladang rumput \\
\hline priksa & dokter/klinik/rumah sakit \\
\hline mulang & kelas/sekolah \\
\hline matun & sawah \\
\hline
\end{tabular}

Tabel 1 berisikan contoh bentuk verba lokatif. Verba lokatif tersebut terdiri dari satu morfem dengan tidak mengalami transposisi. Sedangkan verba lokatif yang mengalami transposisi biasanya berupa polimorfemis, dapat diamati pada tabel 2. Misalnya kata pacul berupa kata benda mengalami transposisi menjadi kata macul sebagai kata kerja.

Tabel 2. Verba Lokatif Polimorfemis

\begin{tabular}{ccc}
\hline VERBA & PROSES MORFOLOGIS & DESKRIPSI \\
LOKATIF & TEMPAT (di) \\
\hline dodolan & dodol $+\{$-an $\}=$ dodolan & warung $/$ pasar \\
\hline
\end{tabular}




\begin{tabular}{ccc}
\hline bal-balan & bal $+\mathrm{R}\{$-an $\}=$ bal-balan & lapangan \\
\hline macul & $\{\mathrm{N}-\}+$ pacul = macul & kebun/sawah \\
\hline olah-olah & olah $+\mathrm{R}=$ olah-olah & dapur \\
\hline nglangi & $\{\mathrm{N}-\}+$ langi = nglangi & sungai \\
\hline ngepel & $\{\mathrm{N}-\}+$ pel = ngepel & rumah \\
\hline mancing & $\{\mathrm{N}-\}+$ pancing = mancing & kolam/sungai \\
\hline ngarit & $\{\mathrm{N}-\}+$ arit = ngarit & kebun/sawah \\
\hline ngulukake & berupa gabungan dua kata yang & lapangan \\
layangan & menjadi frasa & lapangan \\
\hline mepe gabah & berupa gabungan dua kata yang & menjadi frasa \\
nimba banyu & berupa gabungan dua kata yang & sumur \\
& menjadi frasa & tempat potong \\
cukur rambut & berupa gabungan dua kata yang \\
& menjadi frasa & \\
\hline
\end{tabular}

\section{Pembahasan}

Pembahasan mengenai fungsi verba lokatif dalam kalimat tunggal wacana naratif bahasa Jawa akan dibahas secara besamaan. Bentuk verba lokatif berkaitan dengan bidang morfologis yang digolongkan ke dalam bentuk monomorfemis dan polimorfemis. Fungsi dan peran verba lokatif ada kaitannya dengan argumen yang mendampingi dalam satu bentuk kalimat. Fungsi merupakan hubungan antara unsur-unsur bahasa dalam ujaran, sedangkan peran merupakan hubungan predikator dengan sebuah nomina. Pada data berikut ini akan dibahas mengenai bentuk, fungsi dan peran yang mampu ditempati verba lokatif dalam kalimat sebagai berikut.

(2) Siti saben esuk dodolan beras.

'Siti setiap pagi berjualan beras.'

(PS / No. 09 / 2015 / 30) 
Kalimat (2) merupakan kalimat tunggal yang mengandung verba lokatif polimorfemis berupa kata khotbah, dengan struktur kalimat:

$$
\frac{\text { Siti / Nom }}{\mathrm{S}}+\frac{\text { saben esuk / Frasa Adv }}{\text { Ket waktu }}+\frac{\text { dodolan /Verba }}{\mathrm{P}}+\frac{\text { beras / Nom }}{\mathrm{O}}
$$

Kata dodolan dalam kalimat tersebut menempati fungsi P, kata Siti menempati fungsi S, frasa saben esuk menempati fungsi keterangan (waktu), kata beras menempati fungsi O. Adapun kategori kata dodolan berupa verba, kata Siti berupa nomina, frasa saben esuk berupa frasa keterangan waktu, dan kata beras berupa nominal.

Kata dodolan dalam kalimat tersebut merupakan verba lokatif. Dimana verba dodolan mengandung nomina instrumen, sesuatu tempat yang digunakan untuk berjualan. Dengan itu, verba lokatif tersebut bersifat inheren (jenis nomina lokatif sudah tercermin di dalam verbanya). Akan tetapi, nomina yang mengikutinya bersifat bersifat inheren, artinya verba itu sudah mengandung nomina lokatif, yaitu di dapur. Dengan demikian, verba tersebut tanpa diikuti nomina lokatif pun tetap eksis sebagai verba lokatif. Selain itu, verba tersebut membangun relasi lokatif secara intrinsik, artinya arah relasi ke dalam verba itu. Dengan demikian, nomina lokatif pada kalimat (2) bersifat inheren. Keketatan nomina lokatif yang telah tercermin (hadir) di dalam verba lokatif dapat dilihat dengan kurang berterimanya kalimat berikut.

(2a) Siti saben esuk dodolan beras ing pasar.

'Siti setiap pagi berjualan beras di pasar.'

Kehadiran satuan lingual ing pasar 'di pasar' justru membuat kalimat tersebut menjadi kaku dan kurang efektif. Memang, konstituen itu sebagai nomina lokatif, tetapi kehadirannya tidak dibutuhkan karena nomina lokatif itu sudah terkandung dalam verba lokatifnya. Sedangkan peran verba lokokatif dodolan adalah refleksif. Maksudnya, peran yang menyatakan tindakan yang mengenai dan atau dimanfaatkan atau dinikmati oleh yang bertindak sendiri yaitu Siti. Kata dodolan merupakan verba golongan aktif yang bersifat proses. Makna leksikal dodolan yaitu berjualan sesuatu. Makna gramatikal Siti saben esuk dodolan beras 
adalah suatu tindakan aktif (bersifat proses) kepada sasaran (objek) yang dilakukan oleh pelaku.

(3) Simbah nembe sare.

'Simbah baru tidur.'

(DJ/No.12/2019/12)

Verba sare 'tidur' mengandung nomina instrumen, sesuatu tempat yang digunakan untuk tidur yaitu di kamar tidur. Dengan itu, verba lokatif tersebut bersifat inheren (jenis nomina lokatif sudah tercermin di dalam verbanya). Akan tetapi, nomina yang mengikutinya bersifat takintrinsik, artinya, nomina itu bersifat longgar (tidak ketat). Ketidakketatan nomina itu ditandai dengan dapatnya bermacam-macam jenis lokatif yang mampu mengikuti verbanya. Namun demikian, meskipun nomina itu bermacam-macam, jenis nomina itu masih di dalam satu wadah kehiponiman. Dengan demikian, nomina lokatif pada kalimat (3) bersifat takintrinsik. Verba sare 'tidur' pada data (3) secara morfologi berbentuk monomorfemis.

Data (3) merupakan kalimat tunggal yang mengandung verba lokatif monomorfrmis berupa kata sare 'tidur,' dengan struktur kalimat:

\section{$\underline{\text { Simbah/Nom }}+$ nembe sare/FV.}

$\mathrm{S}$

$\mathrm{P}$

Kata simbah dalam kalimat tersebut menempati fungsi S, dan nembe sare 'baru tidur' menempati fungsi P. Adapun kategori yang menempati kalimat (3) adalah simbah sebagai nomina, dan nembe sare 'baru tidur' berupa frase verba. Peran verba lokatif kalimat (3) adalah refleksif. peran argumen pendamping adalah kata simbah sebagai agentif. Makna gramatikal Simbah nembe sare adalah suatu tindakan kondisional (keadaan) yang mengenai dan atau dimanfaatkan atau dinikmati oleh pelaku (agen).

(4) Budhe nembe tandur.

'Budhe baru menanam (padi).'

(JL/No.07/2019/4) 
Verba lokatif tandur 'menanam' pada kalimat (4) bersifat inheren, artinya verba itu sudah mengandung nomina lokatif, yaitu di sawah. Dengan demikian, verba tersebut tanpa diikuti nomina lokatif pun tetap eksis sebagai verba lokatif. Selain itu, verba tersebut membangun relasi lokatif secara intrinsik, artinya arah relasi ke dalam verba itu. Verba tandur 'menanam' pada data (4) secara morfologi berbentuk monomorfemis.

Data (4) merupakan kalimat tunggal yang mengandung verba lokatif monomorfrmis berupa kata tandur 'menanam,' dengan struktur kalimat:

$\underline{\text { Budhe/N }}+$ nembe tandur/Frase Verba. S $\mathrm{P}$

Kata Budhe dalam kalimat tersebut menempati fungsi S, dan nembe tandur 'baru menanam' menempati fungsi P. Adapun kategori yang menempati kalimat (3) adalah Budhe sebagai nomina, dan nembe tandur 'baru menanam' berupa frase verba. Peran verba lokatif kalimat (4) adalah aktif. Peran argumen pendamping adalah kata Budhe sebagai agentif. Makna gramatikal Budhe nembe tandur adalah suatu tindakan aktif yang dilakukan oleh pelaku (agen).

(5) Saiki dheweke wis kuliyah.

'Sekarang dia sudah bersekolah (di perguruan tinggi).'

(PS/No.06/2019/02)

Verba kuliyah 'bersekolah' mengandung nomina instrumen, sesuatu tempat yang digunakan untuk bersekolah yaitu di sebuah perguruan tinggi. Dengan itu, verba lokatif tersebut bersifat inheren (jenis nomina lokatif sudah tercermin di dalam verbanya). Akan tetapi, nomina yang mengikutinya bersifat takintrinsik, artinya, nomina itu bersifat longgar (tidak ketat). Ketidakketatan nomina itu ditandai dengan dapatnya bermacam-macam jenis lokatif yang mampu mengikuti verbanya. Namun demikian, meskipun nomina itu bermacam-macam, jenis nomina itu masih di dalam satu wadah kehiponiman. Dengan demikian, nomina lokatif pada kalimat (5) bersifat takintrinsik. Verba kuliyah 'bersekolah' pada data (5) secara morfologi berbentuk monomorfemis.

Data (5) merupakan kalimat tunggal yang mengandung verba lokatif monomorfrmis berupa kata kuliyah 'bersekolah,' dengan struktur kalimat: 


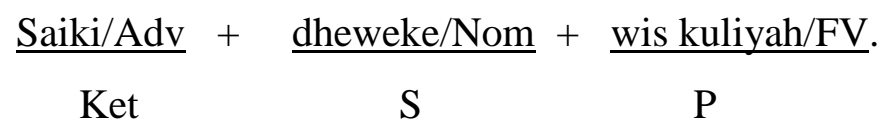

Kata dheweke dalam kalimat tersebut menempati fungsi $\mathrm{S}$, dan kuliyah 'bersekolah' menempati fungsi $\mathrm{P}$, dan kata saiki 'sekarang' menempati fungsi keterangan. Adapun kategori yang menempati kalimat (5) adalah dheweke sebagai nomina, kuliyah 'bersekolah' berupa verba, dan saiki 'sekarang berupa adverbia. Peran verba lokatif kalimat (5) adalah refleksif. peran argumen pendamping adalah kata dheweke sebagai agentif. Makna gramatikal saiki dheweke wis kuliyah adalah suatu tindakan kondisional (keadaan) yang mengenai dan atau dimanfaatkan atau dinikmati oleh pelaku (agen).

(6) Setyo lagi mulang.

'Setyo baru mengajar.'

(JL / No. 04 / 2019 / 31)

Kalimat (6) merupakan kalimat tunggal yang mengandung verba lokatif monomorfemis berupa kata mulang, dengan struktur kalimat:

$\frac{\text { Setyo / Nom }}{\mathrm{S}}+\frac{\text { lagi mulang / FV }}{\mathrm{P}}$

Kata lagi mulang dalam kalimat tersebut menempati fungsi P dan Setyo menempati fungsi S. Adapun kategori yang menempati unsur pembentuk kalimat adalah Setyo sebagai nominal dan lagi mulang berupa frasa verba.

Frasa verba lagi mulang dalam kalimat tersebut merupakan verba lokatif. Dimana verba mulang mengandung verba proses, sesuatu kegiatan atau aktifitas yang dilakukan di kelas atau di sekolah. Dengan itu, verba lokatif tersebut bersifat inheren (jenis nomina lokatif sudah tercermin di dalam verbanya). Akan tetapi, nomina yang mengikutinya bersifat takintrinsik, artinya, nomina itu bersifat longgar (tidak ketat). Ketidakketatan nomina itu ditandai dengan dapatnya bermacam-macam jenis lokatif yang mampu mengikuti verbanya. Namun demikian, meskipun nomina itu bermacam-macam, jenis nomina itu masih di dalam satu wadah kehiponiman. Dengan demikian, nomina lokatif pada kalimat (6) bersifat takintrinsik. Adapun kalimatnya sebagai berikut.

(6a) Setyo lagi mulang ing kelas.

(6b) Setyo lagi mulang ing sekolah. 
Sedangkan peran verba lokokatif mulang adalah refleksif. Maksudnya, peran yang menyatakan tindakan yang mengenai dan atau dimanfaatkan atau dinikmati oleh yang bertindak sendiri yaitu Setyo.

\section{SIMPULAN}

Verba lokatif dalam kalimat tunggal dalam wacana naratif bahasa Jawa (kajian struktur sintaksis) dapat dianalisis dari sisi fungsi. Fungsi dalam kalimat tunggal wacana naratif bahasa Jawa yang terdapat unsur verba lokatif dengan kebanyakan berpola S dan P (dengan kategori verba/frase verba). Sedangkan peran verba lokatif dalam kalimat tunggal wacara naratif bahasa Jawa berupa peran aktif dan peran reflektif.

Kemampuan verba lokatif untuk menghadirkan nomina lokatif dapat bersifat inheren dan takinheren/eksternal. Kemampuan takinheren/eksternal, artinya verba itu harus diderivasikan dahulu untuk dapat menghadirkan nomina lokatif. Bahwa sifat nomina lokatif yang mengikuti verba lokatif inheren, bersifat intrinsik; nomina lokatif yang mengikuti verba lokatif takinheren, bersifat takintrinsik. Namun demikian, ada juga nomina lokatif yang mengikuti verba lokatif inheren, bersifat takintrinsik. Nomina lokatif intrinsik, artinya nomina tersebut bersifat ketat, jelas, dan sudah secara eksplisit terkandung dalam verba lokatifnya. Nomina lokatif takintrensik, artinya nomina tersebut bersifat longgar, umum (general).

\section{DAFTAR PUSTAKA}

Kridalaksana, H. (2011). Kamus Linguistik. Jakarta : PT Gramedia.

Poedjosudarmo, S. dkk. (1979). Morfologi Bahasa Jawa. Yogyakarta : Pusat Penelitian Bahasa.

Sasangka, S.S.T.W. (2008). Paramasastra Gagrag Anyar Basa Jawa. Jakarta: Yayasan Paramalingua.

Subroto, E. (1992). Pengantar Metode Penelitian Linguistik Struktural. Surakarta : Sebelas Maret University Pers. 
Sudaryanto. (1993). Metode Dan Aneka Teknik Analisis Bahasa. Yogyakarta: Duta Wacana University Press.

Sumarlam \& Sujono. (1996). Morfologi Bahasa Jawa. Surakarta: Sebelas Maret University Press.

Verhaar. J.W.M. (2006). Asas-asas Lingyistik Umum. Yogyakarta: Gadjah Mada University Press. 